\title{
Hard Skills Versus Soft Skills: How Do they Affect Different Job Types of Japanese Language Graduates?
}

\author{
Soni Mulyawan Setiana \\ Universitas Komputer Indonesia \\ Bandung, Indonesia \\ Linda Setiawati \\ Universitas Pendidikan Indonesia \\ Bandung, Indonesia \\ Mujahidil Mustaqim \\ Universitas Pendidikan Indonesia \\ Bandung, Indonesia
}

\begin{abstract}
This study aims to analyze the relation between hard skill and soft skill competencies of Japanese language graduates on four different types of job including managers, administrators, communicators, and instructors. This research was conducted through a quantitative approach by distributing questionnaires to 100 alumni of Japanese department from five universities in Bandung, namely Universitas Padjadjaran, STBA Yapari ABA Bandung, Universitas Kristen Maranatha, Universitas Nasional PASIM, and Universitas Komputer Indonesia. The results showed that the ability of hard skills and soft skills of Japanese department graduates is considered relevant to the needs of the world of work where graduates, especially with the type of work communicators tend to have higher hard skills and soft skills compared to other types of work. Hard skills and soft skills have a very close and inseparable relationship because the two are complementary and balance each other. The ability of hard skills for all four types of work is considered good, but the skills in applying information and communication technology have not fully supported the other skills in hard skills. The ability of soft skills in the four types of work is considered to be good because each domain of soft skills has gone hand in hand with one another in forming integrated soft skills. Japanese departments need to continuously strengthen hard skills and soft skills. This aims to enable graduates to compete in the global market.
\end{abstract}

Keywords: Hard Skills; Soft Skills, Job Type; Japanese Language; Graduates. 


\section{Introduction}

Based on the Teikoku Data Bank survey, in Indonesia, there are currently 1,763 Japanese companies, mostly from the manufacturing sector. Still, recently the growth of Japanese companies engaged in services has also increased. The number of Japanese companies investing in Indonesia increased by 39.3\% compared to that in March 2012 with only 1,266 companies. As much as 52.9\% or 932 companies are manufacturing companies, increased by $34.7 \%$ compared to the previous year. Whereas, based on annual sales value, between 10 billion yen to 100 billion yen, the number of Japanese companies has increased by $73 \%$ from 345 companies to 597 companies currently investing in Indonesia. If we take a look at the origin of the Japanese company, 37.9\% of companies coming from Tokyo and surrounding areas are investing in Indonesia (as many as 668 companies). While from Aichi prefectures such as from Nagoya City and so on, there are 214 companies. Most are companies related to the Japanese car and motorcycle industry (Susilo, 2014). Total Japanese investment in Indonesia in the past few years can be seen in the following table 1 :

Table 1. Japanese Investment in Indonesia until September 2018

Source: databooks.co.id

\begin{tabular}{|c|c|}
\hline Year & Amount of Invest \\
\hline 2011 & 1,5 Billion \\
\hline 2012 & 2,5 Billion \\
\hline 2013 & 4,7 Billion \\
\hline 2014 & 2,7 Billion \\
\hline 2015 & 2,9 Billion \\
\hline 2016 & 5,4 Billion \\
\hline 2017 & 5 Billion \\
\hline 2018 & 3,8 Billion \\
\hline
\end{tabular}

Based on Table 1, it is found that the value of Japanese investment in Indonesia experiences ups and downs every year; however, Japan is still a significant investor in Indonesia. Until September 2018, the realization of Japan's direct investment into Indonesia has reached the US $\$ 3.8$ billion or $17.4 \%$ of the total direct investment entering Indonesia. Japanese investors have invested in 2,731 projects in Indonesia.

Japan Bank for International Cooperation survey in 2017 of Japanese manufacturing companies operating outside of Japan placed Indonesia in the fourth position of Japan's investment destination, after China, India, and Vietnam. The results show that Indonesia is still seen as an essential country related to the principal investment objectives. Director of Bank Indonesia, Puji Atmoko explained that there are four positive economic indicators, which are considered by Japanese investors as an advantage of Indonesia as an investment destination, namely a large population; relatively high economic growth in the range of five per cent; improved infrastructure and industrial links; and an increasingly conducive investment climate (Fazza, 2019). 
This is in line with the opinion of Akamatsu (2015), Tomiyoshi (2015), and Susilo (2014) which explains the reasons why more Japanese companies are investing their capital in Indonesia, defined by the following: 1) The large population in Indonesia makes Indonesia a promising market. 2) Most of Indonesia's population consists of the middle layer; this causes their purchasing power to be relatively large. 3) GDP (Gross Domestic Product) in Indonesia is large, 4) Also, abundant natural wealth and cheap labour in Indonesia is also a factor of investment in Indonesia.

Tomiyoshi (2015) further explained that about $70 \%$ of Japanese companies in Indonesia are companies that produce such product as vehicle components. The rest are companies that offer services such as restaurants, insurance, tutoring, and others. In terms of location, most Japanese companies (about 90\%) are in Java. This is because, in terms of raw materials for manufacturing components for spare parts and factories in Java, they are generally based in West Java. Japanese companies such as four-wheeled vehicles have a high market share, approximately $96 \%$, then added by two-wheeled vehicle companies, the percentage is $99 \%$.

The amount of investment and a large number of Japanese companies in Indonesia and supported by an abundant workforce cause the need for graduates, especially Japanese department, to be high. The demand for graduates of this top Japanese literature study program then raises new challenges, namely the quality of graduate output that is matching the employment needs. The high demand for graduates must be accompanied by the quality of graduate output. If the quality of graduate output is neglected, even though the need for such products is high, likely, many graduates will not be absorbed by employment.

The output of graduates of Japanese department, in general, is divided into two, namely hard skills and soft skills. Noe, Hollenbeck, and Gerhart (2015) state: "skills refer to the level of performance of an individual on a particular task or the capability to perform a job well which can be divided into technical elements and behavioural elements". Here it is stressed that skills can be divided into two parts, namely technical elements or what is often called hard skills, and behavioural elements or also commonly called soft skills. Jobs generally divide employee skill requirements into two categories, namely "hard" and "soft" skills (Ahmed et al., 2012). Klaus (2010) states that soft skills determine the success of a job in the long term $75 \%$, and hard skills determine only $25 \%$.

In practice, the hard skill competency of Japanese Literature Study Program graduates includes four aspects, including reading, listening, writing, and speaking. These four aspects of competency are stated in the agreement of an association of Japanese study programs in Indonesia in 2017 while the soft skills competencies of graduates of Japanese department have been arranged and adjusted to the domain attitudes of higher education graduates listed in Law No. 12 of 2012.

The big question that comes to our mind for universities every year is whether the competence of hard skills and soft skills of graduates of Japanese department is currently relevant to the needs of the workforce. Looking at the four types of 
Japanese department graduate jobs, do graduates already have the competencies of hard skills and soft skills when pursuing each of these types of work? If not, then this is an obstacle that must be resolved. What competencies are not yet mastered, and why are they not yet mastered and how urgent are those competencies to be learned. Then, there needs a way for these competencies to be learned by prospective graduates so that graduates will be better prepared academically and experience in dealing with the world of work.

The skill gap of graduates with the demands of the world of work is a significant problem in the higher education environment (Patacsil \& Tablatin, 2017). Most of the college graduates have a waiting period of work of about one year. The reason for the skills gap is that college graduates are not or are lacking in skills or skills in specific fields that are relevant to the world of work. Public and private schools and universities currently face challenges in producing graduates who can meet the demands of the world of work (Song \& Tang, 2016).

The research of Cahyono et al. (2017) suggests that the level of relevance of Universitas Brawijaya Japanese Literature graduates with the world of work related to the field of Japanese is still lacking. It is evidenced by only $54 \%$ of graduates who work by the area of Japanese. According to the result of evaluation from the classes given, there is still a need to hold more courses that support the world of work such as business communication, ethics and Japanese corporate culture and vocabulary around the company. Improvement efforts are also carried out by changing the curriculum involving users of graduates, students and alumni, preparing rules for graduation requirements needed by the workplace, as well as improving learning methods and job training to provide soft competency capital for students.

Budi (2015) explained a large number of tertiary education graduates in Indonesia each year, but many universities did not have an alumni track record. This result in no feedback from alumni that can be used as input for improvement and improvement in the quality of educational programs at their alma mater whereas BAN-PT Kemristekdikti mandates the need to conduct a traceability study of alumni profiles which include the existence of alumni, performance, contributions and alumni association/network in one of the assessment standards for accreditation forms for study programs and/or institutions.

The implementation of tracing studies has a significant role for tertiary institutions to find out the alumni track record and the relationship of tertiary education with employment. Higher education needs feedback from alumni in their efforts to improve education policy and administration. Input from alumni regarding the conditions, experience and motivation will also determine the system and management of tertiary education, so the results will help in shaping the character/competency of the college graduates themselves.

Based on the observations of researchers on hard skill and soft skill competencies of graduates who have worked in the field raised another problem, namely when graduates enter the workforce, graduates often experience obstacles in several specific Japanese terms in the company where the graduates work. The Japanese terms are considered unfamiliar to graduates because they 
only exist in specific companies, for example, machinery companies. Also, some graduates and several Japanese departments in various universities said the main problem of graduates lies more in soft skills. So this research wants to find out in-depth and comprehensively examine whether the Japanese literature curriculum is relevant to the needs of the workforce today and in the future.

If examined from the results of the company assessment report as a user of Japanese literary graduates on the practice of student fieldwork, there are some notes need to be improved by graduates later, including aspects of the initiative, achievement in work, and ability to work. Graduates users expect graduates of Japanese literature in the future when entering the workforce to be more creative in giving birth to new ideas or innovations in the work undertaken. Awkwardness or not being ready to work in the field is something that should be anticipated by prospective graduates before entering the workforce.

Likewise, when looking at the views of alumni of Japanese literature on the competence of current graduates, there are some notes becoming the input to universities in optimizing efforts to form graduate competencies, including prospective graduates who are expected to be more active in communicating daily Japanese both in formal and informal or non-formal conditions and the ability to practice Japanese writing such as e-mail in Japanese and other technical matters. This is partly since up to now there is no tool to measure speaking ability in Japanese, so speaking ability is often a problem of graduates. In the Japanese Language Proficiency Test (JLPT) assessment standards compiled by The Japan Foundation also does not contain indicators of speaking and writing competency assessment so that graduates' ability to communicate and write Japanese is often found to be suboptimal. For this reason, practical training is needed, such as apprenticeship programs in various Japanese companies domestically and abroad. Many factors include rapid technological development, diverse and evolving community needs resulting in the potential needs of the company to also continue to change.

It must be an awareness that if the skills of graduates do not match the needs of the workforce, then graduates cannot be used by users and graduates who have tried to shape their competencies in higher education are in vain. To follow up on this scientifically, the article reveals quantitatively the results of research on whether there is still a relevant relationship between the competencies of hard skills and soft skills of graduates against the four types of jobs graduates of Japanese department.

\section{Literature Review}

Ahmed et al. (2012) stated that each job generally divides skill requirements into two categories, namely "hard" and "soft" skills. Hard skills are requirements and technical knowledge needed by someone to carry out tasks that are following their fields. Meanwhile, soft skills are skills that refer to personality traits and attitudes that encourage personal behaviour (Roan \& Whitehouse, 2007).

Hard skills can be interpreted as a skill that is acquired through training, education or study in the workplace correctly to carry out work tasks. Meanwhile, soft skills are defined as a group of personality traits, social 
solidarity, language skills, friendliness, and optimism. Hard skills are technical skills and knowledge needed to do a job. Traditionally, hard skills are the only skills required to do a job. However, it seems that hard skills alone are not enough for employers to be able to keep individuals employed to work well and to determine the position of a worker in his company (James \& James, 2004). The term hard skills refers to the ability of workers who come from education, training, knowledge, talent, to do things well; excellence incompetent performance; and crafts, trade skills, or jobs that require manual skills or specialized training where a person is required to have competence and experience (Robles, 2012). Hard skills are the achievements included in the resume, such as education, work experience, knowledge, and level of expertise. The examples of hard skills include counting, reading, typing writing, writing, the ability to use software programs, etc. (Investopedia, 2012). Concerning language skills, hard skills include job skills like listening and speaking, reading, writing, translating, using information communication technology (ICT), and cross-cultural understanding.

Furthermore, Bancino and Zevalkink (2007) explained that soft skills are not talent or technical knowledge. Soft skills are skills that have no form, not professional, and are special skills that determine the quality of a person as a leader, facilitator, mediator, and negotiator. Soft skills include character, attitude, and behaviour.

Soft skills are needed at work for professional success. Soft skills are fundamental at every level of the organization if they function correctly, smoothly and productively. Hard skills are technical competencies and knowledge of a field, while soft skills are a combination of one's abilities which include interpersonal skills, communication skills and emotional intelligence (Deepa \& Seth, 2013). The company seeks a combination of soft and hard skills among its employees to deliver excellent and services effectively to clients. Soft skills are work skills that can be transferred in many jobs. Cleary, Flynn, and Thompson (2006) define general work skills as follows:

a. Necessary skills, including technical, task knowledge, direct ability

b. Thinking skills, including planning, collecting and organizing information, and solving problems

c. Business skills, including enterprise and innovation

d. Community skills, including learning about citizenship and society

e. Skills related to others, including interpersonal qualities, such as communication and teamwork

f. Personal skills include being responsible, highly motivated, and confident

Robles (2012) suggests that there are ten types of soft skills expected by employers of employees, including:

a. Having excellent communication skills, including oral and written communication, and presentation skills

b. Having good manners, including understanding business ethics, being friendly, saying sorry, help and thank you, and having respect

c. Flexible, including the ability to adapt, the desire to move forward and develop, have the spirit to continue learning to improve their competence. 
d. Having ethical integrity, including honesty, excellent ethics, and high morality and excellent personality

e. Having excellent interpersonal skills, including having excellent character, excellent sense of humour, friendliness, empathy and self-control are excellent, patient, warm, and friendly.

f. Having a positive attitude, including having an optimistic outlook, passionate, and confident.

g. Having a professional attitude, including having a calm personality, being able to work well, dressing appropriately when meeting customers or working, etc.

h. Having moral responsibilities, including being responsible for what is their duty, being reliable, completing work, having broad insights, etc.

i. Being able to work together in teams, including cooperative attitude, getting along with other people, being friendly, etc.

j. Having a good work ethic, including being able to work hard, be loyal to the company, have excellent initiatives to develop the company, have the right self-motivation, work on time, etc. In relation to language skills, the soft skills include job skills like (a) Ability to Communicate and Solve Problems (b) Collaboration and Life-long Learning \& Information Management (c) Leadership, Entrepreneurship, Ethics and Professionalism (d) Organizational Commitment and Self Development (e) Honesty and Sincerity (f) Integrity and Loyalty.

Various types of research on the importance of soft skills at work have been carried out (Mitchell et al., 2010). The study conducted by Klaus (2010) explained that $75 \%$ of the success of a job in the long term depends heavily on soft skills, while only $25 \%$ depends on hard skills. Furthermore, John (2009) explains that one's success $85 \%$ depends on soft skills. In other words, hard skills only contribute $15 \%$ to one's success, so the company should pay attention to the soft skills of its employees in identifying a position.

Litecky, Arnett, \& Prabhakar (2004) introduced a model for recruiting new workers who combined the importance of hard skills and soft skills. This model uses a variant of behavioural decision theory that appears, called Image Theory by using hard skills tests in the initial stages of screening, and subsequent tests use soft skills tests to determine the actual employee recruitment. This model emphasizes the need for a balance of hard skills and soft skills. In this sense, soft skills complement technical skills, so the ideal employees should possess both (Lewis, 2008).

\section{Method}

This study is a quantitative approach by utilizing questionnaires as the main instrument of data collection. The data were analyzed by descriptive analysis, correlation, and ANOVA. This paper discusses differences that are hypothesized to exist between hard and soft skills based on job types. The population and sample of this research are 100 graduates of Japanese language from five universities in Bandung who work in the Japanese companies, namely automotive industry, electronic industry, chemical industry, tourism/hospitality and property industry, education, and other industries and services. They work 
as managers (18 graduates), administrators (34 graduates), communicators (29 graduates), and instructors (19 graduates).

There are 6 (six) indicators to measure hard skills (HS): listening and speaking (HS1), reading (HS2), writing (HS3), translating (HS4), using information communication technology (HS5), and cross-cultural understanding (HS6). For soft skills there are also 6 (six) indicators: Ability to Communicate and Solve Problems (SS1), Collaboration and Life-long Learning \& Information Management (SS2), Leadership, Entrepreneurship, Ethics and Professionalism (SS3), Organizational Commitment and Self Development (SS4), Honesty and Sincerity (SS5), and Integrity and Loyalty (SS6).

\section{Results}

Descriptive statistics and testing the significance of the average difference for the hard skills and soft skills of Japanese literary study program graduates who work in four professional fields, namely instructors, communicators, administrators, and managers were administered. Hard skills consist of speaking and listening, reading, writing, translating, ICT, and cultural understanding whereas soft skills include the ability to communicate and solve problems, collaborate and perform lifelong learning \& information management, leadership, entrepreneurship, ethics and professionalism, organizational commitment and personal development, honesty and sincerity, as well as integrity and loyalty. The descriptive statistics of hard skills and soft skills based on the type of work are presented in table 2 as follows:

Table 2. Descriptive Statistics of Hard Skills and Soft Skills of the Four Types of Job

\begin{tabular}{|ll|c|c|r|}
\hline \multicolumn{1}{|c|}{ Types of Job } & $\mathrm{N}$ & Mean & Std. Deviation \\
\hline Total Hard skills & Manager & 18 & 4.071 & .493 \\
& Administrator & 37 & 4.188 & .513 \\
& Communicator & 33 & 4.424 & .421 \\
& Instructor & 12 & 4.339 & .367 \\
\hline Total Soft skills & Manager & $\mathbf{1 0 0}$ & $\mathbf{4 . 2 6 3}$ & $\mathbf{4 7 7}$ \\
& Administrator & 18 & 4.108 & .492 \\
& Communicator & 37 & 4.192 & .479 \\
& Instructor & 12 & 4.427 & .354 \\
\hline & Total & $\mathbf{1 0 0}$ & 4.329 & .326 \\
\hline
\end{tabular}

Based on the results of descriptive statistics testing for hard skills and soft skills in terms of different types of work above, it appears that the kind of work communicator has the highest average achievement among other types of work. The mean strength of alumni hard skills who work as communicators is 4,424 with the standard deviation owned is 0.421 ; this means that the strength of alumni hard skills who work as communicators is excellent. Meanwhile, the mean strength of alumni soft skills who work as a communicator is 4,427 with the standard deviation owned by 0,421 ; this shows that the strength of alumni soft skills who works as a communicator is excellent. 
Furthermore, the mean ability of alumni hard skills working as instructors is 4,339 with a standard deviation of 0.367 ; this means that the strength of alumni hard skills who work as instructors are excellent. Meanwhile, the mean strength of soft skills alumni who work as instructors is 4,329 with a standard deviation of 0.326; this shows that the strength of soft skills alumni who work as instructors is excellent.

Graduates who work as administrators have an average ability of hard skills of 4,188 with a standard deviation of 0.513 ; this means that the strength of hard skills of alumni who work as administrators is good. Meanwhile, the mean strength of alumni soft skills who worked as an administrator was 4,192 with a standard deviation of 0.479 ; this shows that the ability of alumni soft skills who worked as an administrator was good. The mean ability of hard skills of alumni who work as managers are 4,071 with a standard deviation of 0.493 ; this means that the strength of hard skills of alumni who work as managers is excellent.

Meanwhile, the mean ability of soft skills of alumni who work as managers is 4,108 with a standard deviation of 0.492 ; this shows that the strength of soft skills of alumni who work as managers is excellent. Based on the above findings, it appears that the average achievement for soft skills in the type of work managers, administrators, and communicators tend to be higher than the hard skills pair, except for the kind of instructor work that has an average performance for hard skills (mean $=4,339$ ) is higher than the average achievement for soft skills (mean $=4,329$ ). The results of this calculation lead to the fact that the profile of graduates of Japanese department who have worked in companies with communicator jobs tend to have the highest hard skills and soft skills compared to other types of work, then followed by instructors, administrators, and managers. This shows that the ability of hard skills and soft skills for communicator work is more needed compared to other occupations. Thus, the outline of the research hypothesis can be answered as follows:

\section{a. Hypothesis I}

Table 3. Significance Test Results of the Difference in Average Hard Skills and Soft Skills Based on the Type of Job

ANOVA

\begin{tabular}{|ll|r|r|r|r|r|}
\hline & & \multicolumn{1}{|c|}{$\begin{array}{c}\text { Sum of } \\
\text { Squares }\end{array}$} & \multicolumn{1}{c|}{ df } & Mean Square & F & Sig. \\
\hline Total Hard Skills & Between Groups & 1.796 & 3 & .599 & 2.769 & .046 \\
& Within Groups & 20.755 & 96 & .216 & & \\
& Total & 22.551 & 99 & & & \\
\hline Total Sof t Skills & Between Groups & 1.556 & 3 & .519 & 2.838 & .042 \\
& Within Groups & 17.551 & 96 & .183 & & \\
& Total & 19.108 & 99 & & & \\
\hline
\end{tabular}

Based on table 3, it can be concluded that the significance value of $0.046<0.05$, then Ho is rejected, which means there is a significant relationship between hard skill competencies with the type of work of graduates of Japanese department. Furthermore, each indicator of the ability of hard skills to the kinds of graduate jobs is explained in the following table: 
Tabel 4. Recapitulation of each Hard Skills Domain Based on Job Type

\begin{tabular}{lcl}
\hline \multicolumn{1}{c}{ Domain Hard skills } & Sig. & Explanation \\
\hline Listening \& Speaking & 0,028 & Different \\
Reading & 0,031 & Different \\
Writing & 0,003 & Different \\
Translate & 0,061 & No different \\
Information and Communication Technology & 0,181 & No different \\
Cross-Cultural Understanding & 0,621 & No different \\
\hline
\end{tabular}

Based on Table 4, it appears that there are differences in the ability to listen and speak, read, write from alumni who work as managers, administrators, communicators, and instructors. Meanwhile, there is no difference in the ability to translate, ICT and cultural understanding of alumni who work as managers, administrators, communicators, and instructors.

\section{b. Hypothesis II}

Based on table 3, it can also be concluded that the significance value of 0.042 $<0.05$, then Ho is rejected, which means there is a significant relationship between soft skill competencies with the type of work of graduates of Japanese department. Furthermore, each indicator of soft skills ability to the kinds of graduates' work is explained in the following table 4:

Tabel 5. Recapitulation of Each Soft Skills Domain Based on Job Type

\begin{tabular}{lcll}
\hline \multicolumn{1}{c}{ Domain Soft skills } & Sig. & \multicolumn{1}{c}{ Explanation } \\
\hline Ability to Communicate and Resolve Problems & 0.944 & No different \\
Life-long Collaboration and Learning \& Information & & & \\
$\quad$ Management & 0.000 & Different \\
Leadership, Entrepreneurship, Ethics, and Professionalism & 0.004 & Different \\
Organizational Commitment and Personal Development & 0.105 & No different \\
Honesty and sincerity & 0.132 & No different \\
Integrity and Loyalty & 0.055 & No different \\
\hline
\end{tabular}

Based on table 5 above, it can be seen that there are differences in the ability of Co-operation and Lifelong Learning \& Information Management as well as the leadership, entrepreneurship, ethics and professional capabilities of alumni who work as managers, administrators, communicators, and instructors. Meanwhile, there is no difference in the ability to communicate and solve problems, the ability of organizational commitment and self-development, the ability of honesty and sincerity and the ability of integrity and loyalty of alumni who work as managers, administrators, communicators, and instructors. 


\section{Discussion}

\section{a. Hypothesis I}

The ability of learning outcomes of graduates of Japanese department shows that in general the alumni who work in the professional fields of managers, administrators, communicators, and instructors state that hard skills, which include the ability to speak and listen, read, write, translate, and that of ICT mastery and cultural understanding obtained during the study in the Japanese Department is excellent and relevant to the field of work undertaken. This is in line with the opinion of Susilo (2017) which explains that in the Revolution 4.0 students are expected to have scientific and technological literacy that is evident from reading, writing, observing, and cultural literacy so that if graduates later enter the community, they will be able to develop competencies that have been it has to be applied in dealing with problems in daily life related to the field in which it deals. The development of student and student capabilities is significant because, in the future, they are expected to create jobs, and solve life's problems.

1) Manager

The ability of hard skills that includes the ability to speak, listen, read, write, translate, ICT, and cultural understanding of alumni of the Japanese department who undergo the profession as managers are excellent. It shows that the courses obtained while attending studies in Japanese department are relevant to the field of work undertaken.

2) Administrator

The ability of hard skills that includes the ability to speak, listen, read, write, translate, ICT, and cultural understanding of alumni of the Japanese department who are profession as administrators are excellent. It shows that the courses obtained while attending studies in Japanese department are relevant to the field of work undertaken.

3) Communicator

The ability of hard skills that includes the ability to speak, listen, read, write, translate, ICT, and cultural understanding of alumni of the Japanese department who undergo the profession as communicators are excellent. It shows that the courses obtained while attending studies in Japanese department are relevant to the field of work undertaken.

4) Instructor

The ability of hard skills that includes the ability to speak, listen, read, write, translate, ICT, and cultural understanding of alumni of the Japanese department who undergo the profession as instructors are excellent. It shows that the courses obtained while attending studies in Japanese department are relevant to the field of work undertaken.

In general, the domain with the lowest average achievement in hard skills is the information and communication technology domain. This Information and Communication Technology Domain can be said to have not gone hand in hand with other fields in overall hard skills. The skills in applying information and communication technology have not fully supported the other capabilities in the hard skills of graduates of Japanese department who work in companies. The lack of skills in applying information and communication technology is caused 
by the lack of efforts to adapt graduates with the development of existing knowledge of information and communication technology.

In this case, Latif (2017) stated that graduates are not yet fully able to apply logical, critical, systematic, and innovative thinking in the context of the development or implementation of science and technology that pays attention to and uses the value of humanities under their fields of expertise. However, the graduates are still in the development stage to get there. For this reason, graduates are expected to be better able to adapt to the development of technology, information and communication to improve language skills, so that they can be aligned with the development of other domains, namely Listening and Speaking; Read; Writing, translating; and Cross-Cultural Understanding.

In connection with these conditions, Bancino \& Zevalkink (2007) emphasized the importance of mastering information and communication technology in developing hard skills, which in turn knowledge can bridge integrated hard skills with soft skills development. The combination of mastery of hard skills and soft skills in relation to information and communication technology can increase competition and individual competitiveness, improve a variety of resources and investments in the fields of innovation and technology deployed by companies for employee Kanematsu \& Barry (2016) also explained that efforts to prepare graduates who are qualified and able to compete globally, and mastering technological development are essential for everyone and essential for the future of a country.

\section{b. Hypothesis II}

Soft skill ability of graduates of Japanese department shows that in general the alumni who work in the professional fields of managers, administrators, communicators, and instructors stated that soft skills, which include the ability to communicate and solve problems, cooperation and lifelong learning \& information management, leadership, entrepreneurship, ethics and professionalism, organizational commitment and self-development, honesty and sincerity, as well as integrity and loyalty are excellent and relevant to the field of work undertaken.

This is in line with the opinion of Noweski et al. (2012) who identify that the competencies and survival skills needed by students in dealing with life, the world of work, and citizenship in the 21st century are emphasized on seven skills, namely: critical thinking skills and problem-solving; collaboration and leadership; dexterity and adaptability; entrepreneurial initiative and spirit; able to communicate effectively both orally and in writing; able to access and analyze information and; have curiosity and imagination

1) Manager

Soft skills ability that includes the ability to communicate and solve problems, collaboration and lifelong learning \& information management, leadership, entrepreneurship, ethics and professionalism, organizational commitment and self-development, honesty and sincerity, as well as the integrity and loyalty of alumni of Japanese department undergoing the profession as a manager is excellent. It shows the ability of soft skills possessed by alumni of 
the Japanese department is seen to have met the demands of the company; relevant to the field of work undertaken.

2) Administrator

Soft skills capabilities that include communication skills and problem-solving, collaboration and lifelong learning \& information management, leadership, entrepreneurship, ethics and professionalism, organizational commitment and self-development, honesty and sincerity, as well as the integrity and loyalty of alumni of Japanese department undergoing the profession as an administrator is excellent. It shows the ability of soft skills possessed by alumni of the Japanese department is seen to have met the demands of the company; relevant to the field of work undertaken.

3) Communicator

Soft skills capabilities that include communication skills and problem-solving, collaboration and lifelong learning \& information management, leadership, entrepreneurship, ethics and professionalism, organizational commitment and self-development, honesty and sincerity, as well as the integrity and loyalty of alumni of the Japanese department undergoing the profession as a communicator is excellent. It shows the ability of soft skills possessed by alumni of the Japanese department is seen to have met the demands of the company; relevant to the field of work undertaken.

4) Instructor

Soft skills capabilities that include communication skills and problem-solving, collaboration and lifelong learning \& information management, leadership, entrepreneurship, ethics and professionalism, organizational commitment and self-development, honesty and sincerity, as well as the integrity and loyalty of alumni of Japanese department undergoing the profession as an instructor is excellent. It shows that soft skills possessed by alumni of Japanese department are considered to have met the demands of the company; relevant to the field of work undertaken.

The explanation above shows that the soft skills ability of Japanese literary alumni in all fields of work that they are involved in is excellent, showing that it is by the learning achievements formulated by the association of Japanese study programs in Indonesia in 2017.

Based on the results of data processing, it is known that the domains that most contribute to soft skills are integrity and loyalty, including 15 abilities, namely complying with the professional code of ethics, complying with the company code of ethics, being honest in managing resources within its authority, taking time to ensure that their actions do not violate the code of ethics, take consistent efforts, be open to customers, admit mistakes when doing wrong, be frank even though it can damage excellent relations, tell the errors of others wisely, be willing to back down when doing unethical actions, obey existing rules, have responsibilities to company, has a sense of ownership, has an excellent interpersonal relationship, has a fondness for work. Thus, if you want to build excellent soft skills, it is necessary to prioritize the development of integrity and loyalty.

In carrying out the work activities of employees will not be separated from integrity, loyalty and work attitude, so that the employee will always carry out 
the work well. Employees feel deep pleasure in the job done. Morrison (2001) explains that integrity has become one of the crucial terms in business ethics which is continuously discussed and applied in organizations. Not a few organizations that include this understanding in the code of ethics that is a reference for members from top management to field implementers in behaviour. Business integrity and leadership are interrelated.

McShane \& Von Glinow (2003) suggested that integrity is used to describe a person's ability to translate his words into real actions; in other words, there is consistency between words and actions. For this reason, commitment is needed to do it. This commitment and flexibility is a criterion that needs to be considered to realize that integrity.

Furthermore, Becker (1998) argues that integrity is a form of loyalty, namely one's determination to hold universal moral values and principles. Honesty is not just about words, but also reflects actions that are in line with universal and rational ethical principles and values. Integrity requires more than loyalty to ethical principles and values that are believed to be accurate by individuals or approved by certain community groups or organizations.

Steers and Porter (2003) explain that loyalty is defined as commitment, namely the extent to which employees identify their workplaces and maintain their membership in the company. Meanwhile, Hasibuan (2013) states that work loyalty is one of the elements used in employee appraisal, which includes a commitment to his job, position and organization. Where commitment loyalty is reflected by the willingness of employees to maintain and defend the organization inside and outside the work of undermining people who are not responsible.

Aspects of work loyalty include compliance/compliance with company regulations, a high sense of responsibility, devotion to the company and the ability of employees to carry out work. The Loyalty of employees in an organization is necessary for the success of the organization itself. According to Reichheld (1996), the higher the commitment of employees in an organization, the easier it is for the organization to achieve organizational goals that have been predetermined by the owner of the organization. As for the opposite, for organizations whose employee loyalty is low, it is increasingly difficult for the organization to achieve its organizational goals predetermined by the owners of the organization.

Baucus \& Beck-Dudley (2005) explain that one form of evaluation of one's integrity in compliance with the corporate code of ethics and company rules can indeed be a corridor of the behaviour of organizational members. However, the adoption of a code of ethics and company rules that are accompanied by a mechanism of punishment and reward has a negative effect. Penalty and reward systems are often used to build and strengthen organizational culture, including suppressing unethical behaviour committed by employees. Unfortunately, significant dependence on a network of penalties and rewards for enforcing codes of conduct and rules will bring individuals within the organization to the consistency of decisions and actions associated with specific punishment or bonuses. 
Steers and Porter (2003) state that the emergence of work loyalty is influenced by four factors, namely: Personal characteristics, including age, years of service, sex, level of education, achievements, race and some personality traits; Job characteristics, in the form of work challenges, job stress, social interaction opportunities, job enrichment, task identification, task feedback and task compatibility; Characteristics of company design, concerning the internal company that can be seen from decentralization, the level of formalization, the level of participation in decision making, has at least demonstrated various levels of association with corporate responsibility, functional dependency and corporate control functions; Work experience gained, including a positive attitude towards the company, a sense of trust in a positive attitude towards the company, a sense of security.

Based on the above, the high integrity and loyalty of alumni who work in Japanese companies show that in general alumni of Japanese department have excellent soft skills, especially in the domain of honesty and commitment as expected by the company. This is because Japanese companies have been able to meet the expectations of employees, such as the presence of excellent work facilities, a conducive work atmosphere, wages and welfare benefits received very decent, individual or employee personal characteristics, company characteristics and professional forms of work, and opportunities for employees to continue to develop themselves.

\section{Conclusion}

Based on the findings and discussion described, several conclusions can be drawn, among others: First, there is a significant relationship between the relationship of the ability of hard skills for the four types of work, but the skills in applying information and communication technology have not fully supported other capabilities in the hard skills. Second, there is a significant relationship between the ability of soft skills in the four types of work, although it must be recognized that efforts to increase soft skill competencies are even more optimal that can be done by companies that employ graduates of Japanese department. Therefore, the Japanese Department needs to strengthen hard skills and soft skills in a more balanced manner. This is important so that graduates can compete globally. Job training, study abroad, and internship in various Japanese companies are examples of programs that can be carried out by Japanese departments to improve students' hard skills and soft skills. Also, tracer study is very important to get input from alumni and input from stakeholders to improve the quality of graduates.

\section{Acknowledgement}

We acknowledge the partial financial support of this research from Direktorat Jendral Pendidikan Tinggi by Kementrian Riset Teknologi dan Pendidikan Tinggi of the Republic of Indonesia. 


\section{References}

Ahmed, F., Capretz, L. F., \& Campbell, P. (2012). Evaluating the Demand for Soft Skills in Software Development. It Professional, 14(1), 44-49. International Journal of Information Processing and Management (IJIPM), 4(3). https:// doi:10.4156/ijipm.vol4.issue3.17

Akamatsu, S. (2015). Jepang Nilai Indonesia Potensial Jadi Sentra Produksi Dunia [ Japan Values Indonesia's Potential as World Production Center]. Retrieved from http://www.antaranews.com/berita/487063/jepang-nilai-indonesia-potensialjadi-sentra-produksi-dunia

Bancino, R., \& Zevalkink, C. (2007). Soft Skills: The New Curriculum for Hard-Core Technical Professionals. Techniques: Connecting Education and Careers (J1), 82(5), 20-22. Retrieved from: https://files.eric.ed.gov/fulltext/EJ764824.pdf

Baucus, M. S. \& Beck-Dudley, C. L. J. (2005) Designing Ethical Organizations: Avoiding the Long-Term Negative Effects of Rewards and Punishments. Journal of Business Ethics, 56, 355-370. https://doi.org/10.1007/s10551-004-1033-8

Becker, T. E. (1998). Integrity in Organizations: Beyond Honesty and Conscientiousness. Academy of Management Review, 23(1). https://doi.org/ 10.5465/amr.1998. 192969

Budi, B. S. (2015). Report Tracer Study ITB 2015. Bandung: ITB Career Center. Retrieved from https://tracer.itb.ac.id/uploads/report/Buku\%20Tracer\%20Study\% 202015.pdf

Cahyono, A. B., Efrizal, \& Dewi, F. P. (2017). Relevansi Lulusan Program Studi Sastra Jepang Universitas Brawijaya Dengan Dunia Kerja Kejepangan [ Relevance of Universitas Brawijaya Japanese Literature Study Program Graduates with the World of Japanese Work]. Jurnal Asa, 4, Retrieved from http://journal.unesa.ac.id/index.php/asa

Cleary, M., Flynn, R., \& Thomasson, S. (2006). Employability Skills. from Framework to Practice. Department of Education, Science and Training Australia. Retrieved from http://www.fmpllen.com.au/uploads/1/2/9/9/12992035/ employability_skills_from_framework_to_practice_an_introductory_guide_for _trainers_and_assessors.pdf

Fazza, A. (2019). BI Ajak Investor Jepang Tambah Investasi Portofolio [BI Invites Japanese Investors to Add Portfolio Investment]. Retrieved from https://republika.co.id/berita/ekonomi/keuangan/pm8p6j318/bi-ajakinvestor-jepang-tambah-investasi-portofolio

Hasibuan, M. S. P. (2013). Manajemen Sumber Daya Manusia (edisi revisi) I Human Resource Management (revised edition)]. Jakarta: Bumi Aksara.

Investopedia. (2012). Hard Skills. Retrieved from http://www.investopedia.com/terms/h/hardskills.asp.

Kanematsu, H., \& Barry, D. M. (2016). STEM and ICT Education in Intelligent Environments. Retrieved from https://construccion.uv.cl/docs/textos/ coleccion02/Texto.06.STEMandICTEducationin IntelligentEnvironments.pdf

Klaus, P. (2010). Communication Breakdown. California Job Journal, 28, 1-9.

Latif, A. (2017). Developing Curriculum of Bachelor in ELT Program Based on the Indonesian National Qualification Framework (KKNI). PREMISE Journal of English Education, 6(1). http://dx.doi.org/10.24127/pj.v6i1.857

Lewis, T. L., Smith, W. J., Bélanger, F., \& Harrington, K. V. (2008). Are technical and soft skills required?: The use of structural equation modelling to examine factors leading to retention in the cs major. In Proceedings of the Fourth International ACM Workshop on Computing Education Research (pp. 91-100), Sydney, Australia http://dx.doi.org/10.1145/1404520.1404530 
Litecky, C. R., Arnett, K. P., \& Prabhakar, B. (2004). The Paradox of Soft Skills Versus Technical Skills in IS Hiring. Journal of Computer Information Systems, 45(1), 69-76. https:// doi.org/10.1080/08874417.2004.11645818

McShane, S. L \& Von Glinow, M. A. (2003). Organizational Behaviour. McGraw Hill, Inc. Retrieved from https://buytestbank.eu/sample/Solution-manual-forOrganizational-Behavior-Emerging-Knowledge-5th-edition-by-Steven-LMcShane.pdf

Morrison, A. P. (2001). The Interpretation of Intrusions in Psychosis: An Integrative Cognitive Approach to Hallucinations and Delusions. Behavioural and Cognitive Psychotherapy, 29(3), 257-276. https://doi.org/10.1017/S1352465801003010

Noe, R. A., Hollenbeck, J. R., \& Gerhart, B. (2015). Fundamental of Human Resource Management. New York: McGraw-Hill.

Noweski, C., Scheer, A., Büttner, N., Von Thienen, J., Erdmann, J., \& Meinel, C. (2012). Towards a paradigm shift in education practises: Developing twenty-firstcentury skills with design thinking. In Design thinking research (pp. 71-94). Springer, Berlin, Heidelberg. https://doi.org/10.1007/978-3-642-31991-4_5

Patacsil, F. F., \& Tablatin, C. L. S. (2017). Exploring the Importance of Soft and Hard Skills as Perceived by IT Internship Students and Industry: A Gap Analysis. Journal of Technology and Science Education JOTSE, 7(3), 347-368. http://dx.doi.org/10.3926/jotse.271

Reichheld, F. F. (1996). The Loyalty Effect: The Hidden Force Behind Growth, Profits, and Lasting Value. Boston: Bain \& Company, Inc.

Roan, A., \& Whitehouse, G. (2007). Women, Information Technology and Waves of Optimism: Australian Evidence on Mixed-Skill Jobs, New Technology, Work and Employment, 22(1), 21-33. https://doi.org/10.1111/j.1468-005X.2007.00181.x

Setiana, S. M. (2019). Relevansi Kurikulum Program Studi Sastra Jepang dengan Tuntutan Dunia Kerja [Relevance of Japanese Literature Study Program Curriculum with Workplace Demands]. Doctoral Dissertation. Bandung: Sekolah Pascasarjana Universitas Pendidikan Indonesia.

Song, T. K., \& Tang, J. (2016). Managing Skills Challenges in Asean-5 Final Report. Retrieved from https://socsc.smu.edu.sg/sites/socsc.smu.edu.sg/files/\%5 B current-domain $\% 3$ Amachine_name $\% 5 \mathrm{D} /$ news_room/Managing \%20Skills \% 20Challenges\%20in\%20ASEAN-5_Final\%20Report.pdf

Steers, R. M., Porter L. W, (2003), Motivation and Work Behaviour, 7th Edition, International Student Edition. Tokyo: Mc Graw-Hill Inc.

Susilo, R. (2014). Jumlah Perusahaan Jepang Yang Berinvestasi di Indonesia [Number of Japanese companies investing in Indonesia]. Retrieved from http://www.tribunnews.com/internasional/2014/06/20/jumlah-perusahaanjepang-yang-berinvestasi-di-indonesia-naik-14-kali

Tomiyoshi, K. (2015). Peran Perusahaan Jepang di Indonesia [ The Role of Japanese Companies in Indonesia]. Materi Kuliah Umum Fakultas Sastra Universitas Al-Azhar, Jakarta bersama Jetro Indonesia. Retrieved from http://fs.uai.ac.id/jepang/ 2015/05/27/kuliah-umum-bersama-jetro-indonesiaperan-perusahaan-jepang-di-indonesia 